\title{
Public Sector and Corruption in Nigeria: An Ethical and Institutional Framework of Analysis
}

\author{
K. C. Ani Casimir'1, E. M. Izueke², I. F. Nzekwe ${ }^{2}$ \\ ${ }^{1}$ Department of Philosophy, Institute of African Studies, University of Nigeria, Nsukka, Nigeria \\ ${ }^{2}$ Department of Public Administration and Local Government, University of Nigeria, Nsukka, Nigeria \\ Email: cepperngo@yahoo.com, eddyizuks@yahoo.com, nzekwe.ify@unn.edu.ng
}

Received 14 May 2014; revised 22 June 2014; accepted 5 July 2014

Copyright (C) 2014 by authors and Scientific Research Publishing Inc.

This work is licensed under the Creative Commons Attribution International License (CC BY). http://creativecommons.org/licenses/by/4.0/

c) (i) Open Access

\section{Abstract}

The paper examines the imperatives of good ethical conduct in the conduct of government business in Nigeria. As government business grows in complexity with the adoption of technological innovations in government, governance in Nigeria's public sector becomes more problematic and ethically tasking as a result of endemic corruption. An evaluation of the collapse of institutional measures and codes of conduct puts in place to ensure high standard of behavior, using institutional theory suggests that moral contradictions in institutional behavior expectation from the public deepen daily. The perceived lack of an effective ethical organizational framework to coordinate the activities of various institutions has astronomically worsened unethical practices such as corruption in the Nigerian public service. The paper recommends a more realistic African traditional approach to ethical restraint of public servants from indulging in corrupt behavior by subjecting them to customary oath taking based upon the theistic values of fear of sin against mother earth (Ani Casimir, 2009), (a departure from the western style, which sees public service as no man's business: Ekene, 2012). These core African values that emanate from theistic humanism should also permeate the various anti-corruption organizational frameworks in Nigeria to coordinate the national fight against corruption in the public sector. The behavioral and errant departure of civil servants and Nigeria's public service from the core human values that ensure transparent private and public conduct of individuals have resulted in underperformance and underdevelopment. It is perceived furthermore that this lack of public service commitment to human values which would have enabled them to consider others above selfish interests, fear divine retribution, dishonor of a good family name, distaste for greed and stealing of public good has weakened the fight against corruption and turned it into a pedantic and cosmetic exercise without results. Therefore, unethical practices and the systemic abandonment of core African human values by the Nigerian public servants oil the wheel of public sector corruption in Nigeria. 


\section{Keywords}

\section{Public Sector, Ethics, Values, Corruption, Institutional Reforms, Institutions Fighting Corruption in Nigeria-ICPC, EFCC, Code of Conduct Bureau \& NAFDAC}

\section{Introduction-The Ethical and Value Background to the Concepts Applied in the Study}

\subsection{Ethics}

Ethics is a set of moral principles that define right or wrong for a person or groups. Ethics is the study of what is morally wrong or right. Bottorff (1997) describes ethics as a body of principles or standards of human conduct that govern the behaviour of individuals and groups. Pollitt (2003) defined ethics as rules of conduct and behaviour, which relate to questions of right or wrong, good or evil. Hornby (2000) defined ethics as a system of moral principles that govern or influence behaviours of a person. A synthesis of the definitions given will view ethics as moral codes of behaviour that are established by a society, organization, individual, group or a country to protect their values. In public administration and organizations, ethics is codes of behaviour written down to protect public values such as public interest, accountability, justice, impartiality, neutrality, responsiveness, etc. Some ethical codes of conduct established to protect and promote the values listed are financial regulation (FR), public service rules, due process, due diligence, or transparency initiative.

Ethics is codes of behaviour established to protect human values. Ethical concern, to ensure high standards of behavior, is not a new phenomenon. Davis (2009) observed that demands for ethical conduct on the part of politicians and public officials predated the modern concern for the rule of law and could be traced to Greek and Roman times. In Africa, Dukor (2010) noted that the overriding role of ethics, religion and the supernatural in the formulation and application of the principle of justice was one distinctive characteristic of African philosophy. He further observed that in Igbo and Akan folk philosophy, ethical dynamics constitutes a check against the loss of control of the societal purpose by the community or its members.

Codes of ethics were enforced to elicit compliance by the society. Dukor said that there were two main ways of executing justice and enforcing ethical codes in a typical African community. One is through the use of curse and the other is through formal oaths. A breach of any of the two could bring either a curse or misfortunate on the culprit. These two ways were hinged on the spiritual supernatural laws and the belief in an unseen impartial superior being. Public trust and confidence on the rulers were very high due to the general belief and fear of those in authority, that any breach of ethical codes could bring calamity on them and even their unborn generations.

\subsection{Values}

Value is that which men desire, expect or forbid. Values are stable long lasting beliefs about what is important in a variety of situations (McShane \& Glinow, 2003). According to Ezeani (2005), values represent what individuals, organizations, nations etc. desire and want. Values differ from individual to individual, group to group, institution to institution, community to community, profession to profession, etc. We have personal values, organizational values, societal values, national values, etc. These values are what are considered internal driving force of a person, organization or a country that propel them toward goal attainment. Most often, people treat values and ethics as if they are the same. Though, there is an element of relatedness values and ethics that refer mainly to internal checks within the individual or organization, while ethics, however, refers to external checks or control. Ethics is codes of behavior that help to uphold or promote the values. For example, a parent whose value is class may tell his children, as the code of conduct (ethics), not to have anything to do with people that are not of the same class. Also a man who values money highly more than human ethical values may establish the following codes of ethics in his relationship with others:

1) He values money and other material resources above God and the theistic values of good human relationships that under gird peaceful growth of primordial African societies;

2) He will never trust anybody with his money; 
3) Doesn't allow people to see that he is rich or wealthy;

4) To steal public resources or money wherever he has such opportunity to engage in bribery or corrupt conduct.

Therefore, ethics is codes of conducts to protect and promote values. Values in public administration and government include accountability, responsiveness, public interest, merit, impartiality and transparency. Each sector, organization, and profession has values and written codes (ethics) of behavior to safeguard such values. There is a huge discrepancy however between the public expectations of value-oiled behavior and the rotten practice of corrupt tendencies and practices of civil servants in Nigeria (Ani: 2012, p. 25).

\subsection{Corruption: A Working Definition}

The Transparency International (TI: 2011) defines corruption operationally as the misuse of entrusted power for private gain or the use of public office for private gain. In other words, use of official position, rank or status by an office bearer for his personal benefit constitutes corruption. Therefore, corrupt behavior would include, bribery, fraud, stealing the public resources, partiality, favoritism, seizure of public assets for private use etc.

However, in the recent time there is an astronomical growth of corruption in the public sector. Corruption scandals and allegations of dishonesty have clearly affected the confidence and trusted that citizens have in public representatives and officials. Davis (2009) said that the result of distrust by citizens of the public sector was apathy to democratic activity in many OECD countries. He noted that high levels of corruption would impact negatively upon economic performance. Corruption is the highest level of unethical behaviour.

In Nigeria, the consequences of high levels of corruption could be easily observed from the state of the roads, unimaginable poor supply of power, the standard of education, proliferation of churches and militia insurgency. Nigerian people have since lost trust and confidence on the public sector. The high levels of corruption in Nigeria can be attributed to the whittling down or non-existence or non-adherence to ethical codes in the public service. There are so many institutions in Nigeria, such as codes of conduct bureau, EFCC, ICPC, courts etc., that should be enforcing ethical codes. However, and paradoxically, the more these institutions are established the more the growth of unethical behaviours. For example, recently courts in Nigeria discharged a former governor of Delta State of corruption charges but the same governor was convicted and jailed in the United Kingdom over the same offence. In 1992 a former governor of Enugu State buried a large sum of public money in his father's grave. The situation in the legislative houses is more worrisome. The legislative house should have been providing a check on the executive. The two national legislatures have been seriously enmeshed in scandals of unethical conducts and corruption. It ranges from oversight committees demanding bribes to the house leadership borrowing a whopping sum of N40 billion naira on behalf of Nigeria's lower house of representatives, from a bank without collateral, under the leadership of Dimeji Bankole, the former speaker who under prosecution by the Economic and financial crimes commission (EFCC).

Unethical and corrupt practices are sources of negative image to a government. Negative image of a country is even worse than corruption. Every citizen suffers from it especially those living outside the country. The litany of the evils of unethical practices is inexhaustible. The legislative committee on ethics is there to protect the values and image of the house and not public interest nor accountability. International organizations such as the World Bank have taken a strong interest in material corruption in recent years. Ethics in the public sector has become a key concern to the European Union. Davis (2009) observed that increasingly governments all over the world are recognizing that ethics is not just an issue for others but that it is necessary for them to clean up their own doorstep, often in the aftermath of revelations about the alleged unethical behavior of both civil servants and politicians. It is necessary to ensure fair and honest behavior of individuals and organizations acting in the public domain.

\subsection{Corruption in Nigeria-A Shocking View}

The most shocking part of the widespread corruption in Nigeria is the fact that it is not anymore within the parameters of how TI defines corruption; it is no longer limited to politicians or the public servants. It has become very common within every section of the society at every level. It is prevalent not only among the rich who are greedy in spite of possessing enough but also among the poor. The fact is that a huge population of Nigerians (Onyishi, 2012: p. 48) is now involved in corrupt practices in one way or the other, either due to greed or due to the so called unethical compulsion to amass public wealth. People have gone to the extent of adulteration of 
food-stuff such as milk, life-saving medicines, motor tires and food supplements (NAFDAC: 2010 report). The image and social integrity of Nigeria have been battered by corruption and Nigerians are seen as criminals in other countries.

\section{A Situational and Institutional Analysis of Nigeria's Public Sector, Public Administration and Government}

The current concern for ethics especially in Nigeria public service is the astronomical level of corruption which is orchestrated by unethical practices in government and among professionals. Unethical practices kill and neutralize organizational values and consequently relegate the organizational objectives to the background. This blurs the organizational objectives. For instance, academic excellence and merit are the cardinal values of a university or any academic institution. If the lecturers start selling grades to the students, the aforementioned values of the institution will be killed and the objective of training high level manpower will not be achieved. Similarly, if the admission process of an institution is bedeviled by unethical practices the value of academic excellence will be a far cry (Scott, 2004: p. 3).

Another reason for the concern is the increasing atheistic behaviour of the society. As observed by Dukor (2010) people in the traditional society serious in theism and believed that if a person acts contrary (unethically) to divine laws, the person suffers a boomerang or nemesis. Currently, the societies behave as if there is no nemesis or boomerang.

The changing structure of relationship between public administration and the citizens and government is another source of concern. For too long, the public administration has been conceived as a pyramid with the government at the top, the apparatus of bureaucracy in the middle, and the citizenry at the bottom, who were passive beneficiaries of services (Tivelli \& Masini, 2007). However, there was a shift from the traditional administration to another model defined as "shared administration" and founded upon collaboration between the administration and the citizens who are regarded as active participants in the fulfillment of public value. There is then need for good ethical conducts to mediate this new sharing and collaborative approach.

There have been new levels and intensity of interactions between and among the public, private and nonprofit sectors which have led to all kinds of partnership, with an associated blurring of responsibilities. This calls for new rules of the game. With the increase in deregulation taking place in many OCED countries, including Nigeria, many new regulatory agencies have been created, often without clarity as to whom the regulators are actually accountable.

Good operational government ethics will reduce apathy to democratic participation and will restore the confidence of the people in government. It will also ensure equity and fairness in the distribution of collective resources such as public utilities, appointments etc. Properly enforced government ethics will be a means of protecting government waste, abuse and ensure that public interest is put above private interest. Therefore, the concern for ethics arose from apathy to democratic participation as it is happening in Nigeria due to unethical practices of politicians. Also there has been waste in government and abuse of government position for themselves and their cronies. These call for vigorous enforcement of ethical codes of conduct.

Finally, public administration has moved to a more business like approach, commonly referred to as New Public Management. In the New Public Management, outsourcing, contracting, privatization, commercialization and public-private partnership are receiving more attention than are the traditional service delivery and the notion of public interest. There is a greater focus on results (outputs and outcomes), and less attention to processes. This will definitely have some unfortunate side-effects. This requires ethics to moderate the two sides.

If processes are not regulated, then some unfair and dishonest processes can occur which may also adversely affect the output. An economically driven values and business management methods in the public sector will adversely affect public interest. There is need for good ethos of public service to manage the New Public Management philosophy.

This paper is hinged on institutional theory as a framework of analysis. Peters (2000a, 2000b) defines an institution as a formal or informal, structural, societal or political phenomenon that transcends the individual level, that is based on more or less common values, has a certain degree of stability and influences behaviour. It considers the processes by which the structures, schema, rules, norms and routines become established as authoritative guidelines for social behaviour. Different components of institutional theory explain how these elements are created, diffused, adopted and adapted over space and time; and how they fall into decline and disuse. 


\subsection{Institutional Theoretical Approach to Understanding Individual Public Behavior in Nigeria}

Institutional theorists believe that institutions not only offer and constrain behavioral alternatives, but they also, up to a certain extent model individual preferences (March \& Olsen, 1995). This means that institutions, directly and indirectly determine the motives guiding individual behavior. There are many approaches to institutionalism; we shall adopt the rational choice approach. The rational choice institutionalism is that institutions are arrangements of rules and incentives, and the members of the institutions behave in response to those basic components of institutional structure (Peters, 2000a, 2000b). The preferences of the members are not modified by their membership in the institution.

In the rational choice approach, institutions are conceptualized as exogenous to the values of the individuals functioning within them. This statement means that it is assumed that individual values will not be altered by involvement with the institution (Peters, 2000a, 2000b). Behavior will change in response to the assortment of opportunities and constraints presented by the structure, but the values that condition behavior are assumed to be unaffected by the institution (Lawton \& Macaulay, 2009: pp. 23-34). In Nigeria, there are several institutions such as ICPC, EFCC, Public Complaints Commission, NAFDAC etc. that work differently in ensuring high standards of behavior in public service and position. These institutions are supposed to affect and influence the behavior of individuals working them and the public service. However, from the rational choice approach, the values of the individuals are not altered by the institution.

\subsection{Evaluating the Operations of Anti-Graft Institutions in Fighting Corruption in Nigeria}

In Nigeria, anti-graft institutions and agencies were set up to fight corrupt behavior among public and private individuals. However effective these institutions are could be measured by the difference between public expectations of reduction in corrupt behavior and the disappointing increase in cases of graft against public and private individuals in Nigeria. Some of these anti-graft institutions are as follows:

\subsubsection{The Economic and Financial Crimes Commission (EFCC)}

According to the Official position as revealed in the EFCC website (2013) the EFCC is an institution set in accordance with Nigerian law to "curb the menace of corruption that constitutes a clog in the wheel of progress; protect national and foreign investments in the country; imbue the spirit of hard work in the citizenry and discourage ill gotten wealth; identify illegally acquired wealth and confiscate it; build an upright workforce in both public and private sectors of the economy and; contribute to the global war against financial crimes.”

\subsubsection{The Independent Corrupt Practices and Offences Commission (ICPC)}

When in 1999, Transparency International Corruption Perception Index rated Nigeria the second most corrupt nation in the world this brought home to Nigerians the extent of its reach and the tragic consequences for effective management of public institutions and development of Nigeria. All indicators showed that the spread of this cancer had pervaded private and public institutions and destroyed the fibre of integrity at all levels of government and even the private sector of the Nigerian economy. The ethical implications of corruption has identified as the erosion of the economic, political, social and moral bases of the country's sustainable development. According to the official views of the ICPC:

It has brought us near the brink and almost rendered us helpless and hopeless. Even religious institutions, the gate keepers of the nation's moral conscience, were not immune to the ravages of the cancer. It became imperative that something drastic had to be done to arrest the rot. This impelled the commitment of the President to tackle corruption head-on and led to the setting up of the ICPC through a legislative act of the National Assembly.

Although the main duty of the commission is to receive complaints, investigate and prosecute offenders. Other duties include education and enlightenment of the public about and against bribery, corruption and related offences. The commission also has the task of reviewing and modifying the activities of public bodies, where such practices may aid corruption. Other duties of the Commission are outlined below from information gleaned from its official website (http://icpc.gov.ng/our-role/):

Section 6 of the ICPC Act 2000 sets out the duties of the Commission as paraphrased in the following: 
1) To receive and investigate complaints from members of the public on allegations of corrupt practices and in appropriate cases, prosecute the offenders.

2) To examine the practices, systems and procedures of public bodies and where such systems aid corruption, to direct and supervise their review.

3) To instruct, advise and assist any officer, agency, or parastatal on ways by which fraud or corruption may be eliminated or minimized by them.

4) To advise heads of public bodies of any changes in practice, systems or procedures compatible with the effective discharge of the duties of public bodies to reduce the likelihood or incidence of bribery, corruption and related offences.

5) To educate the public on and against bribery, corruption and related offences.

6) To enlist and foster public support in combating corruption.

\subsubsection{The Code of Conduct Bureau (CCB)}

The Code of Conduct Bureau as an Institution of monitoring and checking the behaviors of public office holders is not a recent creation or an Institution peculiar to Nigeria alone. In fact the Institution has been in existence as long as the idea of Government was first introduced to mankind, and it can be found in almost all the countries in the world, though it may be going by different name, different structure and different scope. Cap C15 LFN 2004 gives the Code of Conduct Bureau the mandate to "Establish and maintain a high standard of morality in the conduct of Government business and to ensure that the action and behavior of public office holders conform to the highest standards of public morality and accountability." To implement the above mandate the 1999 Constitution of the Federal Republic of Nigeria has provided the Bureau with some legal powers as contained in paragraph 3, part 1(a) of the third schedule of the Constitution to:

1) Receive Assets Declaration by public officers.

2) Examine the declarations in accordance with the requirements of the Code of Conduct law.

3) Retain custody of such declarations and make them available for inspection by any citizen of Nigeria on such terms and condition as the National Assembly may prescribe.

4) Ensure compliance with and where appropriate enforce the provisions of the Code of Conduct or any law relating thereto.

5) Receive complaints about none compliance with of breach of the provisions of Code of Conduct or any law relating thereto, investigate complaints and where appropriate refers such cases to the Code of Conduct Tribunal.

According to the ICPC Official website (2013), the ethical degeneration in public attitude and corruption led to its establishment:

Corruption, greed and materialism have become so deep rooted in our society. More often than not, Public officers tend to see public office not as responsibility to develop our Country for the common good all, but as an opportunity to enrich oneself and the immediate members of one's family. It is this attitude to public office that hindered the emergence of transparent leadership in our polity and led to weakening of our moral values in our society.

From the perspectives of institutional theory, these institutions can influence the behaviors of members but their preferences and values are not modified by the institutions. This implies that establishing more institutions to fight corruption and unethical behaviors will not be able to change the values of the members. The problem, therefore, is the value system of average Nigerian, which is get-rich-quick and prebendalism. Because of the value system, anti-corruption institutions are occupied by people with values different from those of the institutions. The current level of corruption in Nigeria started from minor unethical practices in the public service to coziness, then to collusion within the service and with the outsiders especially contractors. This led to full blown corruption which has reached an international dimension through bribery from multinational corporations and their collusion with local officials.

The code of Conduct Bureau (Public Complaint Commission) and courts were institutions established to tackle unethical practices in the public service. The public service rules and Financial Regulations were there to prescribe the codes of conduct in the public service. The inability of the institutions to contain the unethical practices led to the coziness, collusion and full blown corruption in Nigeria. Government, in response to the new situation established other institutions such as the ICPC, EFCC, Due Process, Federal Character Commission and so on. These institutions were confronted with jurisdictional problems and functional overlaps. For example, 
the ICPC and the EFCC and the public complaints commission have been pursuing alleged corrupt public officials from ex-governors to serving public officials.

Without an organizational framework to coordinate and harmonize the activities of these institutions, each institution tries to register its presence in every case established. They see themselves as rivals instead of being coordinate. In so doing, they end up collecting their own share of loots from corrupt officials. This is because no agency would want to bell the proverbial cat. In most cases the corrupt officials go free since no agency may be prepared to pursue any corruption case to its logical conclusion. Therefore, establishment of anti-corruption institutions is an expansion of conduit pipes of corruption. This is because each new institution will still have the same set of people whose values are different from those of the institutions. To further buttress the effect of differences in values of individuals and institutions, the case of Police Commissioner, BIU comes to mind. It was alleged that the Police Commissioner allowed the mastermind of bombing of a Catholic Church (Mr. Sokoto) to escape from custody. This was because his personal religious value was not the same with the values of the police (institution). Also, a self confessed member of the Boko Haram (Nigeria's acclaimed Islamic terrorist group) was given only three months imprisonment by a Judge of a court. This is another example of where individual preference was not altered by their institutional membership. All these happened in 2012.

\section{Recommendations for Waging a Successful Fight against Corruption- An African Value and Ethical Integration}

In order to move towards good ethical conduct in government and reduce corruption the following measures are suggested we strongly recommend the integration of theistic humanism and core African values in both individual and public conduct of civil servants in Nigeria. It is in the context of this core framework that we recommend further the following as the way forward in waging a succeful war in Nigeria "public and private sector":

\subsection{Ethical Re-Orientation in Schools}

Introduction of ethics in the nation's schools, from primary to tertiary schools would seriously help in re-orientation of the Nigerian people towards good moral conducts. Obalonye (2012) observed that the ICPC has consolidated its strategy against corruption through the introduction of ethics as a core subject in the nation's primary and secondary schools.

\subsection{Theistic Approach and African Values}

From the work of Dukor (2010) we noted that in the early days of the Nigerian society, people fear taking oaths and nemesis due to their belief in God. In Nigeria, there are fiery men of God in Islam and Christianity and even in traditional religious practice that people revere. It is our contention that instead of administering oaths in the court with Bible or Koran, public servants and political officer holders should take the oaths in the churches and Mosques or shrines. For instance, the Catholics can go to Elele where Revered Father Ede is in charge to take oaths, while other denominations can go to places like the Canaan Land for the Winners, Synagogue of all Nations, Redeemed Christian Church of God, etc. The Muslims can go to powerful and revered Imams to take their oath while the traditional worshippers can go to the powerful and popular shrines in their communities for their oaths.

\subsection{Organizational Framework to Coordinate Various Anti-Graft Institutions}

There is an urgent need for an organizational framework to synchronize and harmonize the functions of the institutions in strengthening good ethical behaviours in government. This is to eliminate the unnecessary rivalry among them and to explicitly establish boundaries among them.

\subsection{Political Will}

A strong political will is needed by the leaders to remain neutral in the fight against unethical behaviors and corruption. This will help in strengthening the institutions in the discharge of their functions.

\subsection{Institutional Reforms}

The anti-graft institutions should reformed in such a way that the values of the institutions would alter the values 
of the individuals that work in them. For instance, there should be measures put in places by the judiciary to punish any judge whose individual values is manifested in his judgment against the institutions values.

\subsection{Periodic Retreat for Civil Servants}

It is very disheartening to note that politicians carry out most of the government's activities in the Nigeria state with little or no knowledge of civil service rules, while civil servants are not allowed to perform their normal duties. Even those who do so are negligent of the proper ethical and value implications of proper service delivery in the public sector. To this end, many civil servants have been rendered useless and ineffective. As such, there is urgent need for Nigerian civil servants to try and organize this kind of retreat to acquaint the civil servants with regulations governing the service. The program content of the periodic retreat should be built around core values that emanate from theistic humanism which will help them in resisting the corrupt urge and the motivation for selfish enrichment.

\subsection{Institutionalizing Due Process in the Nigerian Constitution}

Corruption is an unethical conduct either in public or private which basically constitutes an abuse of public office for private gain. It is a malaise that has contempt for due process and the rule of law, distorts the allocation of resources, undermines competition in the market place and has a devastating effect on investment, growth and development. Essentially, corruption denies citizens, especially the poor, access to vital basic services and erodes public confidence in political institutions. The reforms include the review of the public procurement process and institution of the due process mechanism in the award of public contracts. Due process constitutes the ethical enablement of the anti-corruption agencies, processes and the strengthening the transparent management of public resources and institutions. Due process should be more widely empowered through the legislative process and passed by Nigeria's national Assembly.

\subsection{Traditional Oath Taking by Both Private and Public Servants}

Traditional oath taking by both the private and public sector espoused under the metaphysical and moral fabric of theistic humanism (Dukor: 2010, p. 120) should be integrated into the conduct, behavior and operations of government business in Nigeria. In this context, churches, mosques and priests of traditional grottos should administer an ethical oath to every public administrator who is in a position of serving the public. This oath will lead to an ethical individual commitment of the public servant not allow himself to be compromised in the service of the Nigerian public since Nso ani (Fear of mother earth's wrath: Ani Casimir, 2009) is more effective in stopping bad behavior and un-ethical conduct. Surprisingly, unlike the Biblical oaths administered by the Western framework of ethics, this will have a positive impact in reducing the incidence and tendency of corrupt civil servants to steal and compromise due process in the conduct of government business in Nigeria. It arises from the value of the African native that "what is not mine cannot be of value to me or my family; rather it will destroy everybody if I steal what belongs to others" (Ani Casimir, 2009: p. 34). This value and oath taking system should, therefore, be integrated into the programs and activities of Nigeria's anit-graft agencies to make them more effective through individualized ethical and spiritual internationalization of the moral intergrity and the spiritual efficacy of Africa's theistic and humanistic ethics (Dukor, 2010).

\section{Conclusion}

Corruption in Nigeria has reached an alarming proportion. Many institutions have been established to checkmate unethical practices and the corruption. However, the personal values of members of these institutions were not altered by the institutions. Rather the personal values of members alter the values of the institutions. Moreover, the absence of an organizational framework to coordinate the activities of the institutions made them to be independent and competitors rather than being coordinate. This has led to the more abuse of power, corruption and nepotism. An African approach to justice and theism rather than the western style would provide a serious check on unethical practices in Nigeria. It is better to err on the side of caution.

\section{References}

Ani Casimir, K. C. (2009). The Role of Traditional Institutions and Intangible Resources in Cultural Development among 
African Indigenous Peoples: A Religio-Philosophical Exploration of the Ezeagu Wawa Indigenous African People. Journal of African Studies, 10.

Bottorff, D. L. (1997). How Ethics Can Improve Business Success. Quality Progress, 30, 57-60.

Davis, H. (2009). Ethics and Standards of Conduct. In T. Bovaird, \& E. Loffler (Eds.), Public Management and Government. New York: Routledge.

Dukor, M. (2010). African Philosophy in the Global Village: Theistic Panpsychic Relationship, Axiology and Science. USA: LAP LAMBERT Academic Publishing.

Ezeani, E. O. (2005). Fundamentals of Public Administration. Enugu: Snaap Press Ltd.

Lawton, A., \& Macaulay, M. (2009). Ethics Management and Ethical Management. In R. Cox (Ed.), Ethics and Integrity in Public Administration: Concepts and Causes. New York: Sharpe, Inc.

McShane, S. L., \& Glinow, M. A. V. (2003). Organizational Behaviour: Emerging Realities for the Work Place Revolution. Boston: McGraw-Hill Inc.

Obalonye, J. T. (2012). Anti-Graft War: ICPC Introduces Ethics as Core Subject in Schools. Sunday Sun, September 23.

Peters, G. (2000a). Institutional Theory: Problems and Prospects. Political Science Series. Vienna: Institute for Advanced Studies.

Peters, G. (2000b). Institutional Theory in Political Science: The New Institutionalism. London: Continuum.

Pollitt, C. (2003). The Essential Public Manager: Public Policy and Management. UK: Open University Press, McGrawHill Education.

Scott, R. W. (2004). Institutional Theory. In G. Ritzer (Ed.), Encyclopedia of Social Theory. Thousand Oaks, CA: Sage.

Tivelli, L., \& Masini, S. (2002). Un Nuovo Modo Di Governare. Rome: Fazi. 
Scientific Research Publishing (SCIRP) is one of the largest Open Access journal publishers. It is currently publishing more than 200 open access, online, peer-reviewed journals covering a wide range of academic disciplines. SCIRP serves the worldwide academic communities and contributes to the progress and application of science with its publication.

Other selected journals from SCIRP are listed as below. Submit your manuscript to us via either submit@scirp.org or Online Submission Portal.
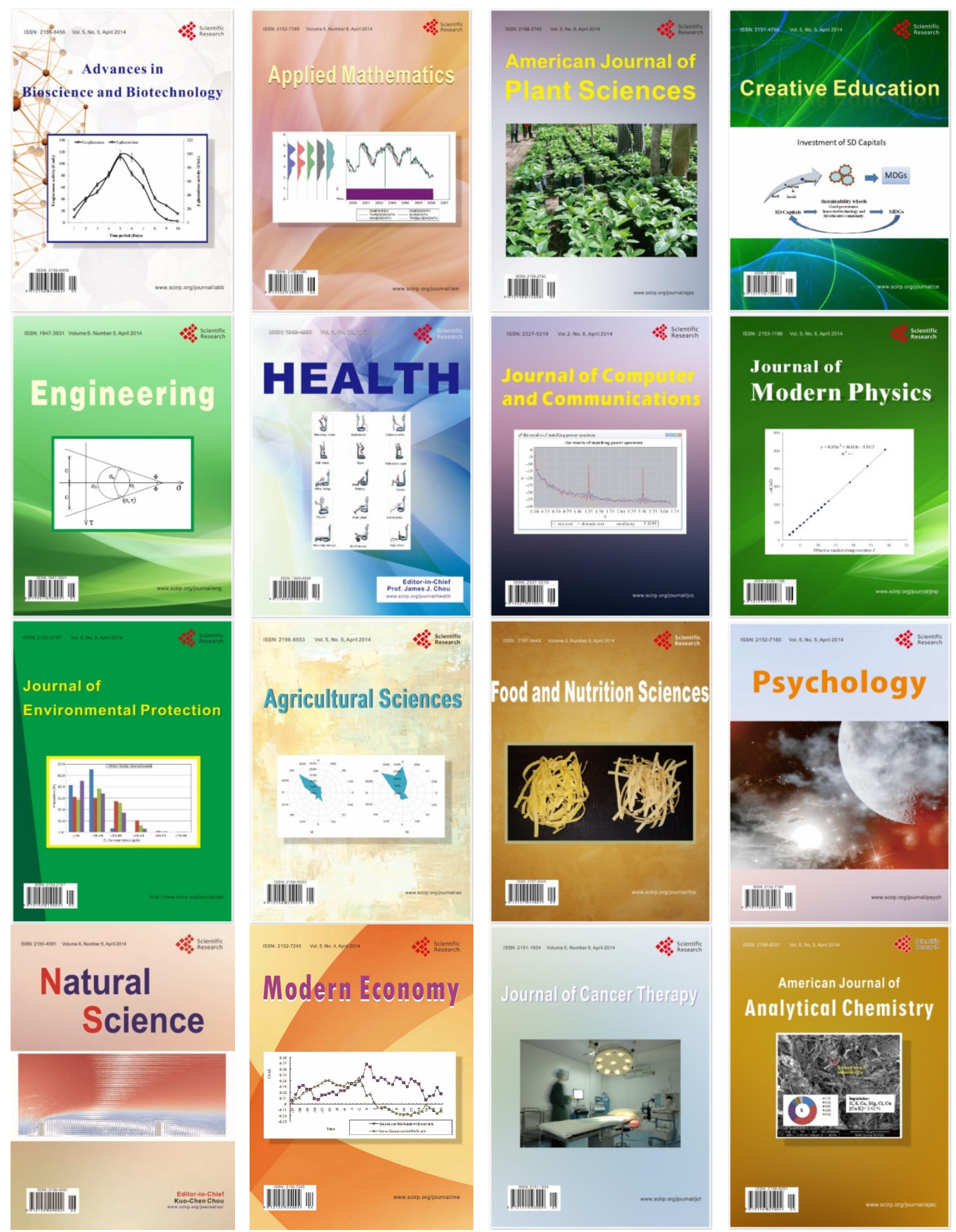